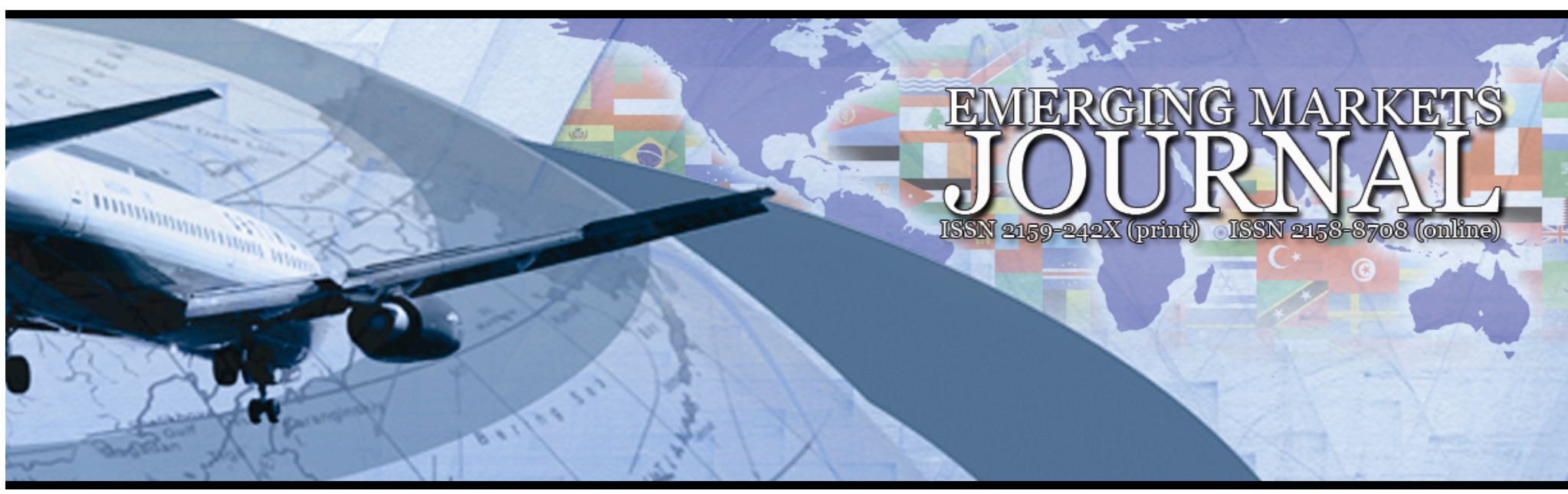

\title{
SERVANT LEADERSHIP AND ORGANIZATIONAL TRUST: THE MEDIATING EFFECT OF THE LEADER TRUST AND ORGANIZATIONAL COMMUNICATION
}

Morad Rezaei

e-mail: morad923@yahoo.com

\author{
Sajjad Salehi Masomeh Shafiei Somaye Sabet
}

Volume 2 (2012) ｜ ISSN 2158-8708 (online) | DOI 10.5195/emaj.2012.21 | http://emaj.pitt.edu

\section{Abstract}

The purpose of this paper aims to clarify the relationship between servant leadership and organizational trust, and tries to demonstrate the mediator role of leader trust and organizational communication in this relationship. The study sample included 258 employees of Guilan province Tax Administration and for sampling we used cluster method. Previous studies have also focused on the positive impact of servant leadership in organizational trust and in this article the results show that there is a significant relationship between servant leadership, organizational trust, leader trust and organizational communication.

Keywords: Servant leadership, Organizational trust, Leader trust, Organizational communication, Iran

\section{(cc) BY-NC-ND}

This work is licensed under a Creative Commons Attribution-Noncommercial-No Derivative

Works 3.0 United States License.

\section{ULIS D-Sonk}

This journal is published by the University Library System of the University of Pittsburgh as part

of its $\underline{\mathrm{D}-\text { Scribe Digital Publishing Program, and is cosponsored by the University of Pittsburgh Press }}$ 
Servant Leadership And Organizational Trust: The Mediating Effect of The Leader Trust And Organizational Communication

\author{
Morad Rezaei \\ Sajjad Salehi \\ Masomeh Shafiei \\ Somaye Sabet
}

\section{Introduction}

The importance of trust in social, economic, and political organization is considered significantly. In studies, organizational trust known as a fundamental factor and the researchers believe that the organizations should creation trust in their employees [3]. Therefore, the leader's behavior is thus more important than that anyone else in determining the level of trust that exists whitin a group or organization [2].

Trust between management and employees will have a large impact on the quality of public management. Thus, the shortage of trust in public organization is one the main factors lead to uninventive and indifferent employees. It seems that the servant leadership is an appropriate solution to address this problem in the government agencies because trust is one of the indicators of servant leadership [7].

Necessity, importance, status and role of leadership in the organization are not secret to anyone. Leadership is a basic need in human society and organizations. Servant leadership is one of the leading figures in the angle of service delivery, growth, development and empowerment is given to the relationship between leader and followers [6].
Servant leadership theory is not a new issue [29]. Because has been implemented in almost all cultures for centuries [35]. Laub (1999) [17] believes the servant leader is a person that insisted on his followers benefits compare to personal benefit. In recent years the understandings of the servant leadership theory has increased [14]. Most of researchers indicate that servant leadership theory can be root of many researches about organizational management and leadership [22].

In fact, the servant leadership have been supported and implemented in some of the most successful American companies [30].

When the model of Meyer et al. [23] was used for the communication between leaders and followers, it was suggested that trust is a function of the leader. Leaders create trust and maintain it through the leader's behavior [12].

Woolston (2001) [34] characterized maintain of cultural norms by leader lead to trust and leader trust depends on leader behavior. Trust grows when people see leaders will become their own honesty to loyalty of organization [16]. The lack of leader trust in work place can lead to dissatisfy of employees [24].

Schweiger and Denisi (1991) [31] found that communication between manager and employees through by telephone, weekly session and news can increase the level of trust in organization and high level of trust between manager and employee can improve job satisfaction in organizations.

Therefore, due attention that trust is one of the main indicator of servant leadership and a main factor for influencing in manager and followers relations we can say that it is a key factor in inter personal communication. In this study we are going to introduce the servant leadership theory, organizational trust and their relationships with the mediating effect of the leader trust and organizational communication. 


\section{Literature Review and Hypotheses}

\section{Servant leadership}

Servant leadership theory presented for the first time by Greenleaf [12]. Greenleaf in response to the question of who is a servant leader in the book, "The role of servant leader," writes one who is servant leader is servant first. Servant leadership begins with a natural feel. It means that a person who has the innate desire to serve [9]. This conscious choice can enthusiastic person to lead others. When people cash good services they will to be a good servant and with this process we will have a good society [1].

According to Greenleaf [11] the leader should first consider the needs of others. In addition, some other authors indicate that servant leadership theory is an authentic and modern theory in organizational leadership.

Servant leadership is a subject that discuss about it in academic and general environment [9]. The definition of servant leadership is a leader who insisted on his followers benefits compare to personal benefit [26]. In Greenleaf's opinion organizations do not deliver good services to the communities. Therefore, he said that by servant leadership the leaders can serve. Servant leadership theory is based on Stewardship theory while traditional leadership theory is based on agency theory [21]. The final goal of Greenleaf is the creation of servant community. A society people can share its benefits and use its advantages. In his view for achieving to this society we should have the servant leaders in all organizations [9]. In fact, he imagined a society that serves to others is always the first choice [18]. Thus, the servant leadership model is not described the organization members who have less abilities compare to his manager, but also gives competence to employees such as managers of the organization. All members have equal dignity and all of them are active and participate in management decisions. Greenleaf believes that servant leadership is based on service philosophy and the servant leaderships prefer the empowerment, trust, cooperation, ethical use of power and serve to others rather than other things [19].

If we believe that the servant leadership is differing from other style therefore, we should introduced different dimensions for it [4]. After reading numerous articles and reviews, 10 features for servant leaders that are enumerated: 1 . Listening, 2. Empathy, 3. Healing, 4. Awareness, 5. Persuasion, 6. Conceptualization, 7. Foresight, 8. Stewardship, 9. Commitment to the growth of people, 10. Building community [17].

\section{Organizational trust}

Several researches from different fields try to define the trust [8]. Cofta (2007) [6] pointed out that trust has 17 different meanings. Also, the definitions of trust between the various fields (psychology, sociology and economics) and the level of analysis (individual, organizational, and social) are different. Shaw [32] defines trust as the belief to achieve our dreams and expectations that are dependent on others. Charlton believes that employees trust their leaders, who want to fulfill job to do [31]. In that organization that trust is low, there is not discipline in works. Low level of trust makes remove the open communication and relations and leads to low quality decisions. In these organizations, employees avoid expressing their idea, because they fear that their plans face failure [10]. The trust not only effect on quality but also can affect on performance, efficiency and effectiveness. Reserachers indicate that organizational trust has direct communication with citizenship behavior, organizational performance and job satisfaction [27].

\section{Leader trust}

Honesty and integrity are essential factors a good leader, based on the history of leadership. 
These values can cause the creation of people trust and organizational trust. Leaders who have honesty can inspiration trust to others [20]. Nyhan (2007) [26] defines trust as an extent of assurance of a person abilities from others view. Joseph and Winston (2005) [15] says the servant leadership known as some unique behaviors that trust is one of them. The trust climate can establish a good organizational climate and facilitate the participation [26]. Bennis and Nanus (1999) [4] believes that the capacity to generate and maintain trust is a central element in leadership.

\section{Organizational Communications}

The concept of organizational communication tactics has been developed by Yamaguchi (2005), based in studies of influence tactics. Influence tactics are "the tactics used by people at work to influence their superiors, coworkers, and subordinates [35]. Organizational communication is the transfer point between members. When exchange information and ideas occur that the purpose transferred from one person to another [5]. Communication between management and employees through a newsletter, telephone, and weekly meetings can reduces uncertainty and will increase job satisfaction, commitment and reliability and honesty increases [10].

\section{Development of Hypotheses}

For this study at first we evaluated the literature and then selected the servant leadership and its dimensions as independent variable and organizational trust as the dependent variable. Leader trust and organizational communication have mediate role. Conceptual model of research based on various theoretical studies shows in Figure 1 and indicated the relationship between servant leadership and its dimensions with organizational trust due attention to leader trust and organizational communication. According to this model, the hypotheses are developed.

Based on a conceptual model the research hypotheses are as follows:

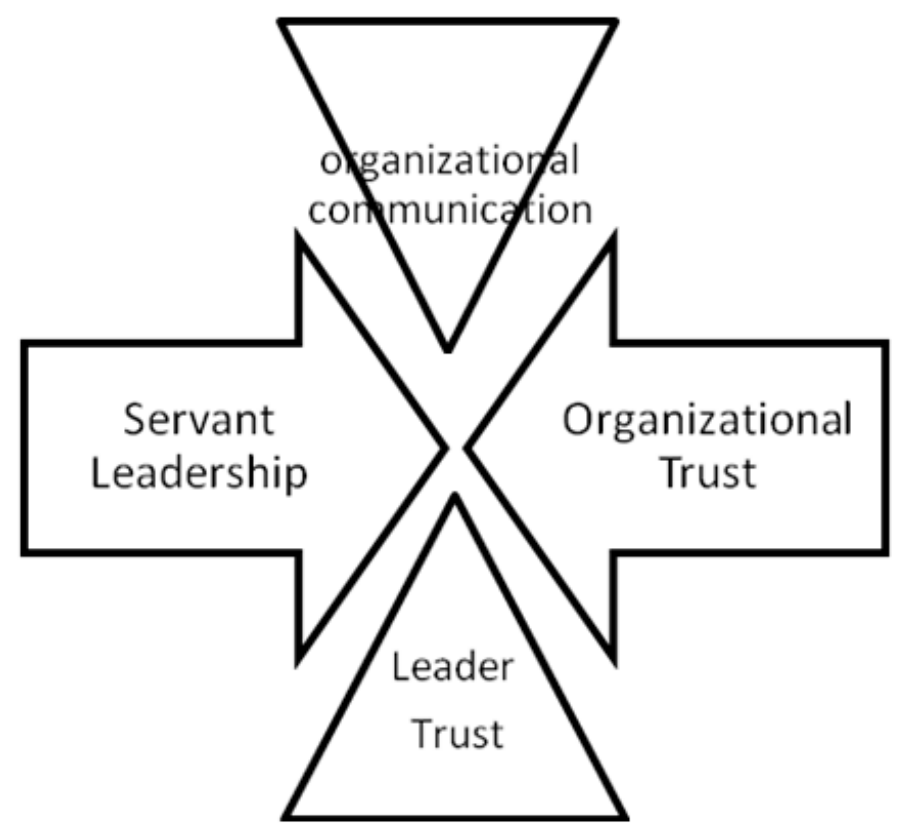

Figure1. Conceptual model of research 
H1: There is a significant relationship between servant leadership and organizational trust.

$\mathrm{H} 2$ : There is a significant relationship between servant leadership and organizational trust due attention to leader trust.

H3: There is a significant relationship between servant leadership and organizational trust due attention to organizational communication.

\section{Methodology}

\section{Research Method}

This study is descriptive and we survey the real attitudes and behavior of employees and managers in the workplace. Variables don't control and manipulate and for implementation of research do not create the artificial environment. For data collection we used different methods and to investigate relationship between variables field studies method is applied. Therefore, this study is a survey research and applicable.

\section{Sample and Data Collection}

The statistical populations of this study are the employees of Tax Affairs in Guilan Province. Sample study based on limited population formula was 258. Data collection tools in this research are four separate questionnaires for assessing servant leadership capital and organizational trust due attention to leader trust and organizational communication.

\section{Measures}

Servant leadership questionnaire design based on Dennis (2004) [7] and Leiden et al. (2005) [20] ideas and includes 36 questions and for the indigenous construction of the questionnaire's and for measure its validity we used factor analysis and 8 questions was removed and the number of questions was reduced to 28 questions. Organizational trust and leader trust questionnaires includes the 12 questions that 8 question was for organizational trust and 4 questions was for leader trust design by Nyhan and Marlowe (1997) [26]. Organizational communication questionnaire design based on Schweiger and Denisi (1991) [31] ideas and includes 5 questions.

To test the questionnaires reliability we used Cronbach's $\alpha$ scores for each variable as shown in Table 4. If the calculated alpha is greater than 70 percent, indicating high credit questions and questionnaires are reliable. In this research the reliability scores were high. Also, for measure the validity of questionnaires researchers used the idea of ten experts that were selected among the faculty of the University (an expert in the field of research) and executives' managers.

\begin{tabular}{cccc}
\hline Table4. Cronbach's $\boldsymbol{\alpha}$ Scores & & & \\
\hline Questionnaire & No. & Cronbach $\boldsymbol{\alpha}$ & Scale Sources \\
\hline Servant Leadership & 28 & 0.83 & Leiden et al. (2005); Dennis (2004) \\
\hline Organizational Trust & 8 & 0.73 & Nyhan and Marlowe (1997) \\
\hline Leader Trust & 4 & 0.74 & Nyhan and Marlowe (1997) \\
\hline Organizational Communication & 5 & 0.71 & Schweiger and Denisi (1991) \\
\hline
\end{tabular}




\section{Test of hypotheses}

1. Relationship between the servant leadership and organizational trust

Based on the above relation, the first hypothesis was given test by Pearson correlation due attention to table 2 .

First hypothesis: there is a significant relationship between the servant leadership and organizational trust in the Tax Affairs of Guilan.
The results of statistical tests of this hypothesis indicate that in a significant percentage "there is a significant relationship between the servant leadership and organizational trust in the Tax Affairs of Guilan ". The intensity of relation between these two variables is 0.593 and this represents a direct link between them. Therefore, this hypothesis is generally confirmed with the $\% 99$ confidence level in the Tax Affairs of Guilan.

\begin{tabular}{llcc}
\hline & & & Table 2. Test of hypothesis \\
\hline \multirow{3}{*}{ Organizational Trust } & & Organizational Trust & Servant Leadership \\
\cline { 2 - 4 } & Pearson Correlation & 1 & $.593^{* *}$ \\
\cline { 2 - 4 } & Sig. (2-tailed) & & .000 \\
\cline { 2 - 4 } Servant Leadership & $\mathrm{N}$ & 258 & 258 \\
\cline { 2 - 4 } & Pearson Correlation & $.593^{* *}$ & 1 \\
\cline { 2 - 4 } & Sig. (2-tailed) & .000 & 258 \\
\cline { 2 - 4 } & $\mathrm{N}$ & 258 & \\
\hline
\end{tabular}

2. Relationship between the servant leadership and organizational trust due attention to leader trust

Based on the above relation, the second hypothesis was given test by Pearson correlation due attention to table 3 .

Second hypothesis: there is a significant relationship between the servant leadership and organizational trust due attention to leader trust in the Tax Affairs of Guilan.

The results of statistical tests of this hypothesis indicate that in a significant percentage "there is a significant relationship between servant leadership and organizational trust due attention to leader trust in the Tax Affairs of Guilan". The intensity of relation between these variables is 0.631 and this represents a direct link between them and shows that with entire the mediate variable (leader trust) in relationship between servant leadership and organizational trust the intensity of relations increase 3.8 percent. Therefore, this hypothesis is generally confirmed with the $\% 99$ confidence level in the Tax Affairs of Guilan.

\begin{tabular}{|c|c|c|c|c|c|c|c|c|c|}
\hline \multirow[b]{3}{*}{ Model } & \multirow[b]{3}{*}{$\mathrm{R}$} & \multirow[b]{3}{*}{ R. S. } & \multirow[b]{3}{*}{$\begin{array}{l}\text { Adjusted } \\
\text { R. S. }\end{array}$} & \multirow[b]{3}{*}{ S. E. } & \multicolumn{5}{|c|}{ Table 3. Test of second hypothesis } \\
\hline & & & & & \multicolumn{5}{|c|}{ Change Statistics } \\
\hline & & & & & $\begin{array}{c}\text { R. S. } \\
\text { Change }\end{array}$ & $\begin{array}{c}\mathrm{F} \\
\text { Change }\end{array}$ & $\mathrm{df1}$ & $\mathrm{df} 2$ & $\begin{array}{c}\text { Sig. F } \\
\text { Change }\end{array}$ \\
\hline 1 & .631 & .398 & .397 & 2.53688 & .398 & 84.443 & 2 & 255 & .000 \\
\hline
\end{tabular}


3. Relationship between the servant leadership and organizational trust due attention to organizational communication

Based on the above relation, the third hypothesis was given test by Pearson correlation due attention to table 4 .

Third hypothesis: there is a significant relationship between the servant leadership and organizational trust due attention to organizational communication in the Tax Affairs of Guilan.

The results of statistical tests of this hypothesis indicate that in a significant percentage "there is a significant relationship between servant leadership and organizational trust due attention to organizational communication in the Tax Affairs of Guilan". The intensity of relation between these variables is 0.643 and this represents a direct link between them and shows that with entire the mediate variable (organizational communication) in relationship between servant leadership and organizational trust the intensity of relations increase 5 percent. Therefore, this hypothesis is generally confirmed with the $\% 99$ confidence level in the Tax Affairs of Guilan.

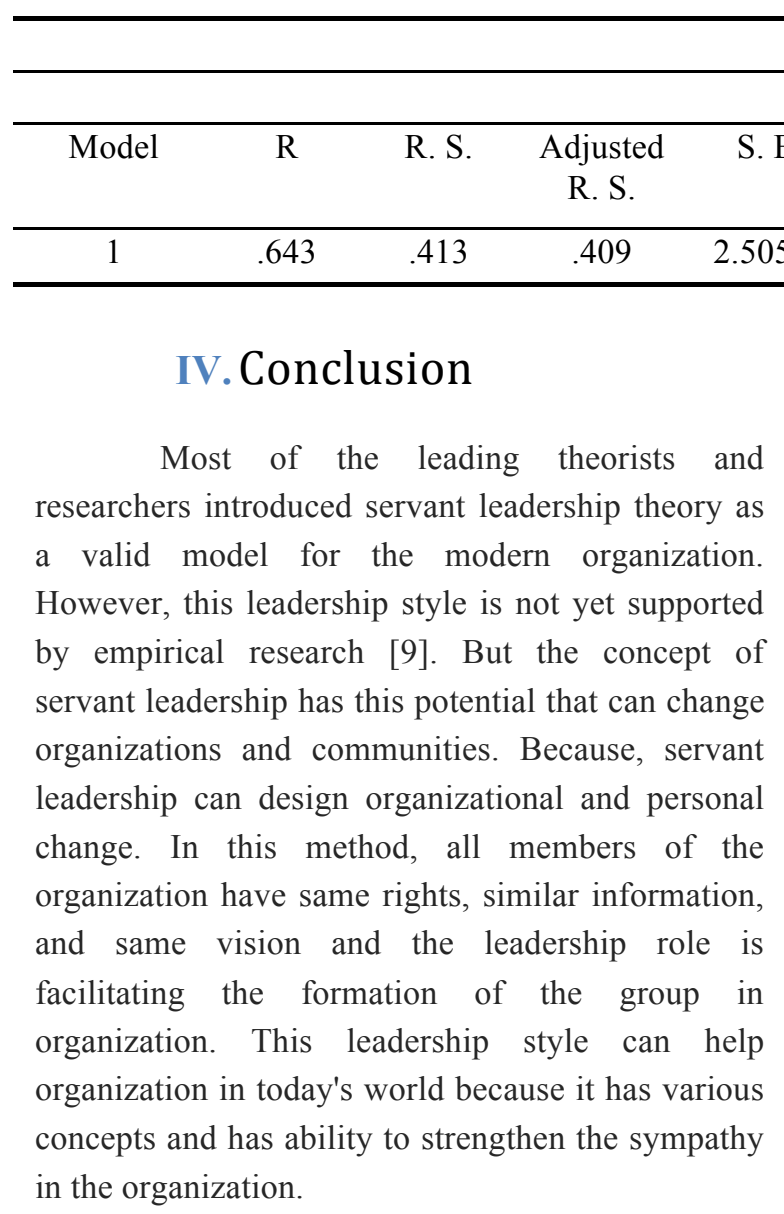

Table 4. Test of third hypothesis Change Statistics

\begin{tabular}{lccccc}
\multicolumn{6}{c}{ Change Statistics } \\
& $\begin{array}{c}\text { R. S. } \\
\text { Change }\end{array}$ & $\begin{array}{c}\text { F } \\
\text { Change }\end{array}$ & df1 & df2 & $\begin{array}{c}\text { Sig. F } \\
\text { Change }\end{array}$ \\
\hline 0542 & .413 & 89.800 & 2 & 255 & .000 \\
\hline
\end{tabular}

Trust is one of the concepts that will affect on relationship between leader and follower. Leaders who are trusted by their followers can easily make sense of commitment and responsibility in their followers. Trust to leaders can affect on many results of organizations and based on many research trust in one of the main dimension of servant leadership. So the servant leadership style can be a good mechanism for building trust in the organization [17], [26], [30].

This research shows that there is as relationship between servant leadership and organizational trust and with entire the leader trust and organizational communication as moderator the intensity of this relationship was increased. This finding is related to previous studies provide evidence of relationship between servant leadership and organizational trust due attention to leader trust [15] and organizational communication. 


\section{References}

1. Andersen, J.A. (2009),"When a servant leadership comes knocking", Leadership \& Organizational Development Journal, Vol. 30, No. 1, pp. 4-15.

2. Aryee, S.; Budhwar, p.s.; Chen, Z. X. (2002),"Trust as a mediator of the relationship between organizational justice and work outcomes: test of a social exchange model", Journal of organizational Behavior, No. 23, pp. 267-285.

3. Baried, A.; Amand, R. (1995),"Trust within the organization", Monograph, Issue 1.

4. Bennis, W.; Nanus, B. (1997)"Leaders: strategies for taking charge", New York: HarperCollins publishers.

5. Bennis, W. (2002),"Become a tomorrow leader", in Spears, L.C. (ED), Focus on leadership: Servant leadership for the 21st Century, Wiley, New York, NY. pp. 101-109.

6. Cofta, P. (2007),"Confidence, trust and identity", BT technology Journal, Vol. 25, No. 2, pp. 173-178.

7. Dennis, R. S. (2004), "Servant leadership theory: Development of the servant leadership theory assessment instrument", A Dissertation presented for the degree Doctor of philosophy.

8. De Pree, M. (1997),"Leading without power: Finding Hope in serving Community", Jossey-Bass Publishers, San Francisco, CA.

9. Fridell, M.; Belcher, R. N.; Messner, P. E. (2009),"Discriminate analysis gender public school principal servant leadership differences", Leadership \& Organizational Development Journal, Vol. 30, No. 8, pp. 722763.

10. Gopinath, C.; Becker, T. E. (2000),"Communication, procedural justice, and employee attitudes: relationships under conditions of divestiture", Journal of Management, Vol. 26, No. 1, pp. 63-83.

11. Greenleaf, R. F. (1970),"The Servant as leader", The Greenleaf center, Indianapolis, IN.

12. Greenleaf, R. F. (1977),"Servant leadership: A journey into nature of legitimate power and greatness", Paulist Press, Mahwah, NT.

13. Horsman, J. H. (2001),"Perspectives of servant leadership and spirit in organization", A Dissertation for the degree Doctor of Philosophy, Gonzaga University.

14. Humphreys, J. H. (2005),"Contextual implications for transformational and servant leadership", Management Decision, Vol. 43, No. 10, pp.1410-1431.

15. Joseph, E.; Winston, B. (2005),"A correlation of servant leadership, leader trust and organization trust", Leadership \& Organizational Development Journal, Vol. 26, No. 1, pp. 6-22. 
16. Kuczmarski, S. S.; Kuczmarski, T. D. (1995),"Values- based leadership, Prentice-Hall, Paramus. NJ.

17. Laub, J. A. (1999),"Assessing the servant organization: development of the servant organizational leadership Assessment (SOLA) instrument", unpublished doctoral dissertation, Florid Atlantic university, Boca Raton.

18. Laub, J. (2004),"Defining Servant Leadership: A Recommended Typology for Servant Leadership Studies", Servant Leadership Roundtable, pp. 1-12.

19. Lee, H. J. (2004),"The role of competence based trust and organizational identification in continues improvement", Journal of Managerial Psychology, Vol. 19, No. 6, pp. 623-639.

20. Liden, R. C.; Wayan, S. J.; Zhoa, H.; Henderson, D. (2005),"Development of multidimensional measure of servant leadership", Management association, Charleston, SC.

21. Levering, R.; Moskowitz, M. (2000),"The 100 best companies to work for in America", Fortune, Vol.141, No.1, pp. 82-110.

22. Martins, N. (2002),"A model for managing trust", International Journal of manpower, Vol. 23, No. 8, pp. 756757.

23. Mayer, R. C.; Davis, J. H. (1995),"An Integrative Model of Organizational Trust", Academy of Management Review, Vol. 20, No. 3, pp. 709-734.

24. Nyabadza, G. W. (2003),"leadership at the peak- the 10th trait of effect leaders", Servant Leadership Zimbabwe In dependent -AAGM, February 7.

25. Nyhan, R. C.; Marlowe, H. A. (1997),"Development and Psycolometric Properties of the Organizational Trust Inventory", Evaluation Review, Vol. 21, No. 5, pp. 614-535.

26. Nyhan, R. C. (2000),"Changing the paradigm: trust and its role in public sector an organizations", American Review of public Administration, Vol. 30, No.1, pp.87-109.

27. Robbins, S. P. (2002),"Fundamental of organizational behavior", translated by Ali Parsaeiyan and Mohammad A'rabi, Cultural Researches Bureau, 5th edition, Tehran, [in Persian].

28. Ronald, W.; Lawrence, D. (2007),"organizational trust, trust in chief executive and work satisfaction", Public Personnel Management, Vol. 36, No. 2, pp. 165-179.

29. Russell, R. (2001),"The role of value in servant leadership", Leadership \& Organizational Development Journal, Vol. 22, No. 2. pp. 76-83.

30. Sendjaya, S.; Sarros, J. C. (2002),"Servant leadership: its origin, development, and application in organizations", Journal of leadership and organizational studies, Vol. 9, No. 2, pp.57-64. 
31. Schweiger, D. M.; Denisi, A. S. (1991),"Communication with employees following a merger: A longitudinal field experiment", Academy of Management Journal, No. 34, pp. 110-135.

32. Shaw, R. (1997),"Trust in the balance", Published by Jossey-bass.

33. Waddell, J. T. (2006),"Servant leadership", School of leadership studies, Regent University.

34. Woolston, R. L.(2001),"Faculty perceptions of dean transitions: does trust matter", Dissertation Abstracts International,UMI, No.3007300.

35. Yamaguchi, I. (2009),"Influences of organizational communication tactics on trust with procedural justice effects: A cross- cultural study between Japanese and American workers", International Journal of Intercultural Relations, No. 33, pp. 21-31. 